\title{
KOMUNIKASI INTERPERSONAL, SOLUSI ALTERNATIF MENGATASI KEJENUHAN RUTINITAS IBU RUMAH TANGGA
}

\author{
Ulin Nihayah \\ Universitas Islam Negeri (UIN) Walisongo Semarang \\ e-mail: ulin_nihayah@yahoo.com
}

\begin{abstract}
Saturated feeling often experienced by man as an individual. Attitude saturation on this individual, addressed with a mixed response. Not a few people who stuck with the feeling of saturation that result in actions that might be considered negative because it harms him, one of them housewives. Feeling tired or bored of the routines performed by housewives if not addressed will result in stress that will have an impact on the problem of domestic life. As one altemative that is done to overcome this stress is to do with interpersonal communication with a partner. Interpersonal communication is intended to help in order to solve problems related to boredom experienced by a housewife.
\end{abstract}

Keywords: saturation; housewife rutinity; interpersonal communication

\section{A. Pendahuluan}

Idealnya sebuah pernikahan adalah suatu bentuk kerjasama antara suami dan istri. Hal ini yang pastinya diharapkan oleh setiap pasangan. Perkawinan dapat diartikan sebagai sebuah ikatan lahir batin seorang pria dan seorang wanita sebagai suami istri dengan tujuan membentuk keluarga (rumah tangga) yang bahagia dan kekal berdasarkan Ketuhanan Yang Maha Esa (UU No. 1 tahun 1974 tentang Perkawinan). Demikian juga hidup berumah tangga dengan mempunyai buah hati, dianggap sebuah pelengkap dalam kehidupan berkeluarga. Mendampingi anak tumbuh besar sekaligus memotivasi suami dalam berkarir adalah sebuah pekerjaan dan tugas yang mulia sebagai seorang ibu rumah tangga. Selain bertugas dalam pengaturan kebutuhan keluarga, seorang ibu bertugas sebagai pengatur sirkulasi keuangan pendapat dan pengeluaran dalam rumah tangga. Beberapa ibu lebih memilih menghabiskan waktunya di rumah untuk men- 
dedikasikan dirinya serta seluruh waktunya untuk mengurus suami dan anaknya. Mencurahkan segenap perhatian, kasih sayang dan bertanggung jawab terhadap tugas dedikasinya tersebut.

Beberapa ayat al-Qur'an yang berkaitan dengan hak dan kewajiban seorang istri juga berpengaruh terhadap peran istri dalam rumah tangga, salah satunya firman Allah:

"Kaum laki-laki itu adalah pemimpin bagi kaum wanita, oleh karena Allah telah melebihkan sebahagian mereka (laki-laki) atas sebahagian yang lain (wanita), dan karena mereka (laki-laki) telah menafkahkan sebagian dari harta mereka. sebab itu Maka wanita yang saleh, ialah yang taat kepada Allah lagi memelihara diri. Ketika suaminya tidak ada, oleh karena Allah telah memelihara (mereka). wanita-wanita yang kamu khawatirkan nusyuznya, Maka nasehatilah mereka dan pisahkanlah mereka di tempat tidur mereka, dan pukullah mereka. kemudian jika mereka mentaatimu, Maka janganlah kamu mencaricari jalan untuk menyusahkannya. Sesungguhnya Allah Maha Tinggi lagi Maha besar." (QS. al-Nisa: 34)

Nampaknya implementasi dari ayat diatas, dipahami bahwa posisi istri dalam bimbingan seorang pemimpin yaitu suami sebagai seorang leader dalam rumah tangga memang secara mutlak. Seorang suami tidak bisa bertindak sebagai seorang pemimpin dalam rumah tangga, tanpa adanya bantuan dari seorang istri yang bertindak sebagai asisten manajer dalam rumah tangga. Kepemimpinan disini tidak dimaknai dengan tindak semena-mena atau pun melakukan kekerasan dalam rumah tangga (KDRT), akan tetapi lebih pada bimbingan yang berbentuk kasih sayang antara suami dan istri

Beberapa hadits juga menyebutkan bahwa peran istri berupa ketaatannya terhadap suami menjamin sebabnya masuk surga, dalam hadits:

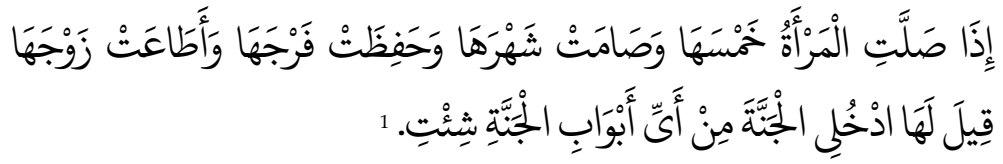

${ }^{1} \mathrm{HR}$. Ahmad 1: 191 dan Ibnu Hibban 9: 471. Syaikh Syu'aib al- Arnauth mengatakan bahwa hadits ini shahih. 
"Jika seorang wanita selalu menjaga shalat lima waktu, juga berpuasa sebulan (di bulan Ramadhan), serta betul-betul menjaga kemaluannya (dari perbuatan zina) dan benar-benar taat pada suaminya, maka dikatakan pada wanita yang memiliki sifat mulia ini, "Masuklah dalam surga melalui pintu mana saja yang engkau suka."

$$
\text { وليس على المرأة بعد حق الله ورسوله أوجب من حق الزوج }
$$

"Tidak ada hak yang lebih wajib untuk ditunaikan seorang wanita setelah hak Allah dan Rasul-Nya- daripada hak suami."2

Jelaslah adanya peran istri ini memang menjadi pendamping suami yang pada hakikatnya bukan kedudukan yang lebih tinggi atau lebih rendah, akan tetapi kerjasama atau kolaborasi peran dalam keluarga.

Mengungkapkan peran istri seolah mengungkap feminisme sebagai peran seorang perempuan yang memang mempunyai tugas-tugas yang tidak ringan. Posisi istri dalam rumah tangga dari hasil pengolahan data Badan Pusat Statistik yaitu Survei Sosial Ekonomi Nasional 2004. Didapatkan data di perkotaan sebagian besar ibu usia kurang dari 40 tahun yang mempunyai anak, hanya mengurus rumah tangga saja (63.3\%) dan yang bekerja hanya $29.6 \%$ saja. Sedangkan di Pedesaan, ibu (dengan kreteria di atas) yang mengurus rumah tangga saja sekitar $52.7 \%$ dan yang bekerja sekitar $41.1 \%$. Dari data tersebut dapat disimpulkan bahwa perhatian seorang istri sebagai ibu rumah tangga masih menjadi sebuah tugas utama dalam keluarga, selain menjadi pendamping suami.

Menurut Baroleh dan Yusri, ironisnya dalam praktik keseharian perempuan yang tidak bekerja dianggap mempunyai posisi yang lemah dan tidak berdaya dalam menghadapi tindak kekerasan yang menimpa dirinya. ${ }^{3}$ Lebih lanjut lagi, posisi perempuan yang hanya berprofesi sebagai ibu rumah tangga semakin hari terlihat semakin rawan pada kejahatan dalam rumah tangga (KDRT). Hal ini menyatakan, bahwa posisi sebagai ibu rumah tangga merupakan tugas yang berat, akan tetapi disisi lain rentan akan resiko dalam melaksanakannya.

${ }^{2}$ Majmu' al-Fatawa, 32: 260.

${ }^{3}$ Astuti, dkk, Hubungan antara kemandirian dengan sikap terhadap kekerasan suami pada istri yang bekerja di Kelurahan Sampangan Kec. Gajah Mungkur Kota Semarang, Jurnal Psikologi Universitas Diponegoro Vol.3 No. 1, Juni 2006, h. 51. 
Masalah yang mungkin dialami karena kejenuhan akan rutinitas, apabila tidak terselesaikan dengan baik maka akan berdampak pada kehidupan berumah tangga pada seorang ibu rumah tangga dan menjadi sebuah stressor dalam kehidupannya. Oleh karena itu, dibutuhkan problem solving dalam rangka menghindari kejenuhan rutinitas yang dialami oleh seorang ibu rumah tangga.

\section{B. Peran Istri sebagai Ibu Rumah Tangga}

Kemulian terbesar yang diberikan Allah bagi seorang istri, adalah menjadi seorang ibu. Bahkan dalam haditsnya Rasulullah bersabda: ketika ditanya oleh seseorang "Wahai Rasulullah, siapakah orang yang paling berhak untuk kuperlakukan dengan baik?" Beliau berkata, "Ibumu." Lakilaki itu kembali bertanya, "Kemudian siapa?", tanya laki-laki itu. "Ibumu". Laki-laki itu bertanya lagi, "Kemudian siapa?", tanya laki-laki itu. "Ibumu", "Kemudian siapa?" tanyanya lagi. "Kemudian ayahmu", jawab beliau." (HR. Al-Bukhari no. 5971 dan Muslim no. 6447).

Peran istri juga seorang ibu ini dibagi dua menjadi dua, ada ibu yang berperan sebagai seorang ibu rumah tangga, ada peran ibu yang berperan seabai ibu pekerja. Ibu sebagai seorang pekerja adalah seorang ibu yang mencari nafkah dengan double job, yaitu dengan menjadi pengasuh, pendidik anak juga sebagai seorang pekerja. Ibu rumah tangga adalah wanita yang mengatur penyelenggaraan berbagai macam pekerjaan rumah tangga. ${ }^{4} \mathrm{Ada}$ anggapan bahwa seorang istri dianggap tidak bekerja, bila kegiatan yang dilakukan adalah melakukan tugas-tugas rumah tangga dan atau mengurus keluarga saja. Dari pernyataan diatas, profesi ibu rumah tangga masih dipandang sebelah mata sebagai sebuah profesi yang kurang mulia.

"Profesi" sebagai ibu Rumah tangga merupakan sebuah spesialisasi, karena dibutuhkan keahlian khusus dan bukan merupakan pekerjaan yang remeh dalam menjalani profesi tersebut. Adapun peran penting ibu rumah tangga dalam keluarga diantaranya:

1. Ibu sebagai manager. seorang ibu rumahtangga mampu mengintegrasikan berbagai macam karakter, berbagai macam keadaan/kondisi anggota keluarganya ke dalam satu tujuan rumahtangga).

${ }^{4}$ Anton Moeliono, Kamus Besar Bahasa Indonesia, Jakarta: Balai Pustaka, 1988), h. 319. 
2. Ibu sebagai guru. Ibu merupakan guru pertama, seorang ibu mampu mendidik putra-putrinya, mengajarkan sesuatu yang baru, melatih, membimbing mengarahkan serta memberikan penilaian baik berupa reward maupun punishment yang mendidik.

3. Ibu sebagai chef. Sebagai seorang chef tentu seorang ibu harus pandai memutar otak untuk berkreasi menghasilkan menu-menu yang dapat diterima semua anggota keluarga, baik menu sarapan, makan siang, maupun makan malam.

4. Ibu sebagai perawat. Ibu rumahtangga juga berperan menjaga kesehatan keluarga, dan apabila ada salah satu anggota keluarga yang sakit turut merawatnya.

5. Ibu sebagai accountant. Sebagai seorang akuntan, seorang ibu mampu mengelola APBK (Anggaran Pendapatan dan Belanja Keluarga) dengan sebaik-baiknya.

6. Ibu sebagai design interior. Ibu sebagai seorang design interior seorang ibu harus mampu menciptakan/menata berbagai turnitur yang ada di rumahnya untuk menciptakan suasana baru, tidak membosankan anggota keluarganya.Sehingga rumah nyaman untuk di tempat keluarga.

7. Ibu sebagai dokter. Ibu sebagai seorang doktor bagaimana seorang ibu harus mampu mengupayakan kesembuhan dan menjaga putra-putrinya dari berbagai hal yang mengancam kesehatan. ${ }^{5}$

Grote dan Clark menyatakan bahwa banyaknya tugas yang dijalani oleh seorang istri, khususnya ibu rumah tangga, membuat perasaan jenuh atau bosan sehingga kurangnya perhatian dari suami dan menjadikannya tidak bahagia pada perkawinannya. Pembagian tugas, antara istri yang berperan sebagai ibu rumah tangga dipersepsikan ketidakadilan mengenai pembagian tugas yang diasosiasikan dengan konflik dan ketidakpuasan perkawinan. ${ }^{6}$

Terdapat tahapan peran pada ibu rumah tangga, di tahap perkembangan dewasa awal (21-35 tahun) dan ibu rumah tangga pada tahap perkembangan dewasa tengah (36-53 tahun), memiliki keinginan untuk

${ }^{5}$ Baqir Sharif al-Qarashi, Seni Mendidik Islami: Kiat-Kiat Menciptakan Generasi Unggul. (Jakarta: Pustaka Zahra, 2003.), h. 64.

${ }^{6}$ Baron. R.A. \& Byrne, D. 2005. Psikolologi sosial. Jilid 2. Edisi 10. Alih bahasa: Ratna Djuwita. Erlangga: Jakarta 
mengisi waktu luangnya dengan berbagai kegiatan untuk mengaktualisasikan diri, dan mencari pemenuhan kebutuhan hidup mereka, sehingga mereka dapat menjadi manusia yang aktif dan produktif. ${ }^{7}$ Adanya keinginan untuk mengerjakan sesuatu yang dinamis, akan tetepi ketika perkerjaan itu terus dilakukan akan berdampak pada bentuk statis dari rutinitas seorang ibu rumah tangga, apalagi yang tidak bekerja dan hanya berfokus pada urusan keluarga dan segala pemenuhannya.

Ketika beranjak masa kanak-kanak dan bersekolah, seorang ibu akan ditinggalkan anaknya untuk bersekolah atau meninggalkan rumah, sehingga terdapat perasaan kesepian. Untuk menjadi stay at home, ibu rumah tangga terkadang timbul perasaan kurang puas. Kesepian yang ia rasakan terkadang menjadi penyebab timbulnya perasaan kebosanan dan berlanjut pada Stress. (Goliszek, 2005) Biasanya stres timbul di karenakan mandapat ancaman baik dalam diri individu ataupun psikologinya (Roediger, 1984). Respons terhadap stres pada manusia sangat terpersonalisasikan dan bervariasi bagi setiap orang bahkan pada individu pada saatsaat berbeda-beda. Gejala stres terjadi setiap hari. Karena itu banyak orang yang mengabaikan dan menganggapnya sebagai hal yang biasa. Memang banyak kondisi yang berhubungan dengan stres sehingga terasa biasa. Salah satu teori stres yang paling populer menyatakan bahwa individu yang toleran terhadap stres memiliki sikap hidup yang terkendali. Di lain pihak individu yang mengalami stres merasa tidak berdaya terhadap peristiwa-peristiwa yang ada di sekitarnya, jika tidak diatasi maka berdampak negatif (Goliszek, 2005).

\section{Kejenuhan Peran Ibu Rumah Tangga}

Menjadi seorang ibu rumah tangga bukanlah hal mudah dilakukan, dalam menyelesaikan pekerjaan rumah tangga ini, seorang ibu rumah tangga membutuhkan energi dan waktu dalam menyelesaikan. Kondisi ini menciptakan rutinitas yang pastinya akan dilakukan dengan kesehariannya. Kebosanan dalam pekerjaan yang monoton secara luas diakui sebagai efek samping yang tidak diinginkan dikarenakan kebosanan dalam mengerjakan pekerjaan yang berulang-ulang. ${ }^{8}$ Bukan itu saja, kejenuhan dalam me-

7Koran Jakarta, “Produktif Ala Ibu Rumah Tangga”, 27 Mei 2010, http://bataviase.co.id/ node/226783.

${ }^{8}$ Thackray, R., The Stress of Boredom and Monotony: A Consideration of the Evidence, (Elsevier North Holland, Inc. New York, 1981). 
laksanakan rutinitas dalam keseharian seorang ibu rumah tangga, juga berdampak pada masalah-masalah rumah tangga yang lain. Menurut penelitian Sukma Ayu (1998) masalah yang terkadang dialami oleh ibu rumah tangga yang tidak bekerja disebabkan oleh masalah dengan suami, masalah dengan anak, masalah keuangan, anggaran rumah tangga yang semakin mahal, masalah terhadap diri sendiri, masalah dengan pekerjaan rumah tangga, masalah keluarga, campur tangan mertua.

Menurut survey hasil penelitian $40 \%$ istri di Jakarta berselingkuh karena suami yang kurang perhatian pada istri. ${ }^{9}$ Terkadang seseorang berselingkuh itu untuk menguji dirinya dengan faktor lain misalnya, seperti kebosanan dalam perkawinan dan kurang komunikasi antara suami istri sehingga akan menimbulkan perselingkuhan (Mossasi, 1999).

Bertambahnya usia perkawinan, pasangan suami istri akan semakin sulit melakukan penyesuaian perkawinan karena pertumbuhan keluarga. Ada banyak hal yang menyebabkan suatu rumah tangga mengalami masalah atau mungkin berada pada ambang keretakan. Misalkan saja, kesibukan suami dan istri, tidak terjalinnya komunikasi yang baik, buruknya pengasuhan anak, masalah keuangan, hilangnya 3 kepercayaan, ataupun masalah seksualitas. Hal-hal tersebut merupakan sedikit dari masalah yang dialami oleh pasangan yang membina rumah tangga. (Wahyuningsih: 2005)

Saat menjalani sebuah pekerjaan sesuai dengan apa yang diharapkan, terkadang menjadi hal yang sangat mengasyikkan bagi seorang Istri, apalagi mengabdikan diri pada keluarga. Perkerjaan yang berkaitan dengan rumah tangga, merawat anak, dan beberapa pekerjaan rumah yang lain, semula menjadi sebuah keasyikkan. Namun pada kelamaannya berubah menjadi hal yang membosankan. Spesialisasi pekerjaan rumah tangga yang dilakukan oleh seorang istri, salah satu faktor penyebab terjadinya suatu kebosanan rutinitas. Kejenuhan atau kebosanan kerja memang hal yang lazim terjadi, namun hal ini menjadi masalah yang sulit, ketika kebosanan terjadi terus menerus pada sebuah rutinitas. Berbagai faktor yang dapat menyebabkan terjadinya kebosanan dalam berkerja antara lain: stress, penurunan kinerja dapat mengakibatkan ibu rumah tangga yang menangani

${ }^{9}$ Www.lulukpr.multiply.com, 2005. 
perkerjaan harian harus kadang kala berhenti terhadap apa yang menjadi kesehariannya sehingga terjadi kebosanan.

Ada tiga jenis kebosanan, yang dijabarkan dalam bentuk kebosanan pada saat bekerja diantaranya adalah: saat individu dilarang untuk berkecimpung dalam beberapa aktivitas yang diinginkan, dipaksa untuk terlibat dalam beberapa aktivitas yang tidakdiinginkan, atau ketika individu hanya melakukan kegiatan yang ada tanpa memiliki perasaan khusus terhadap kegiatan yang ada..$^{10}$ Lebih lanjut faktor dan penyebab seseorang dihinggapi perasaan kebosanan dan menjenuhkan yang diantaranya adalah: 1) Tidak adanya atau kurangnya aktivitas dan kegiatan. 2) Kegiatan atau aktivitas yang monoton dan tidak berkembang. 3) Menunggu sesuatu yang tidak pasti atau terlalu lama. 4) Tidak adanya teman atau terpenjara sepi Keinginan yang belum terlaksana, dll.

\section{Komunikasi Interpersonal Altemative Problem solving}

Gangguan psikologis, berkisar pada kejenuhan atau kebosanan yang bertumpu pada stressor bisa berdampak pada penyakit mental yang serius dan menyebabkan ketidakseimbangan biokimia. Pada jenis kepribadian tertentu, individu yang mudah terkena dampak stress, akan berakibat pada penyakit fisik seperti jantung dan sebagainya. Pengobatan secara holistic tidak akan bisa menjadi penawar, sehingga dibutuhkan penanganan khusus terhadap komponen psikologis terhadap pasien.

Permasalahan kejenuhan terhadap rutinitas sebagai ibu rumah tangga perlu diatasi dengan segera, jika tidak akan berakibat pada munculnya ketegangan atau bahkan sikap apatis, suami-istri berjalan sendiri-sendiri mengikuti idealisme masing-masing. Sikap keterbukaan sangat mempengaruhi keberlangsungan komunikasi dalam rangka problem solving. Pengungkapan terhadap apa yang menjadi pokok masalah harus disampaikan. Jadi, apabila ada sikap yang kurang terbuka dari si penyampai pesan dan reaksi dari si penerima pesan segera mungkin dapat sangat berpengaruh terhadap proses komunikasi yang dilakukan.

Theodorson (1969) mengungkapkan komunikasi adalah pengalihan informasi dari satu orang atau kelompok kepada orang lain, terutama de-

\footnotetext{
${ }^{10}$ Amparo Oliver, Jose Manuel Tomas and Alistair Cheyne, "Safety Climate : Its Nature and Predictive", Psychology in Spain, Vol. 10 No. 1, (2006), h. 28-36.
} 
ngan menggunakan simbol. ${ }^{11}$ Lebih lanjut lagi menurut Arni Muhammad, Komunikasi dedefinisikan sebagai "Pertukaran pesan verbal maupun non verbal antara si pengirim dengan si penerima pesan untuk mengubah tingkah laku".(Muhammad Arni: 2005: 5) Jadi dari uraian di atas komunikasi merupakan proses pertukaran informasi secara verbal maupun non verbal kepada individu atau organisasi dan menimbulkan efek.

Komunikasi interpersonal merupakan bagian dari komunikasi efektif yang dilakukan oleh manusia. Sehingga komunikasi ini tidak bersifat statis. Adapun ciri dari komunikasi interpersonal antara lain:

1. Komunikasi interpersonal adalah komunikasi verbal dan non verbal.

2. Komunikasi interpersonal mencakup perilaku tertentu, adapun perilaku yang dimaksud antara lain:

a. perilaku spontan (spontaneous behaviour) adalah perilaku yang dilakukan karena desakan emosi dan tanpa sensor serta revisi secara kognitif.

b. perilaku menurut kebiasaan (script behaviour) adalah perilaku yang di pelajari dari kebiasaan sehari-hari. Perilaku ini khas. Dilakukan pada situasi tertentu dan di mengerti orang. Perilaku ini sering dilakukan tanpa terlalu mempertimbangkan artinya dan terjadi secara spontan karena sudah mendarah daging dalam diri.

c. perilaku sadar (contrived behaviour) adalah perilaku yang dipilih karena dianggap sesuai dengan keadaan yang ada. Perilaku ini dipikirkan dan dirancang sebelumnya, dan disesuaikan dengan orang yang akan dihadapi, urusan yang harus diselesaikan, dan situasi serta kondisi yang ada.

3. Komunikasi interpersonal adalah komunikasi yang berproses pengembangan.

4. Komunikasi interpersonal mengandungkan umpan balik, interaksi, dan koherensi.

5. Komunikasi interpersonal berjalan menurut peraturan tertentu.

6. Komunikasi interpersonal merupakan kegiatan aktif.

7. Komunikasi interpersonal saling mengubah.

\footnotetext{
${ }^{11}$ Alo Liliweri Komunikasi Antarpribadi, (Bandung: Citra Aditya Bakti, 1991).
} 
Menurut Gerald R. Miller memahami proses komunikasi interpersonal menurut pemahaman hubungan simbiotis antar komunikasi dengan perkembangan relasional, Komunikasi mempengaruhi perkembangan relasional, dan pada gilirannya (secara serentak), perkembangan relasional mempengaruhi sifat komunikasi antara pihak-pihak yang terlibat dalam hubungan tersebut. ${ }^{12}$

Pada penyembuhan gejala kejenuhan ibu rumah tangga, salah satu alternatif dalam terapi ini yaitu komunikasi interpersonal melalui komunikasi terapeutik. Komunikasi terapeutik bukan hanya tertuju pada pasien yang tertuju pada penyakit secara fisik saja, akan tetapi lebih bertumpu pada pasien dalam hal ini konseli dalam rangka menumbuhkan kesehatan mentalnya terhadap gejala kejenuhan sebagai dampak stressor.

Komunikasi terapeutik sendiri adalah komunikasi yang direncanakan secara sadar, bertujuan dan kegiatannya dipusatkan untuk kesembuhan pasien/konseli. ${ }^{13}$ Komunikasi teraperutik juga dipersepsikan sebagai proses interaksi antara klien dan perawat yang membantu klien mengatasi stress sementara untuk hidup harmonis dengan orang lain menyesuaikan dengan sesuatu yang tidak dapat diubah dan mengatasi hambatan psikologis yang menghalangi realisasi diri. ${ }^{14}$

Adapun fungsi komunikasi terapeutik -menurut Vancarolis- adalah mendorong dan menganjurkan kerjasaman antara konselor-konseli melalui hubungan konselor-konseli. Konselor berusaha mengungkapkan perasaan, mengidentifikasi dan mengkaji masalah serta mengevaluasi tindakan dalam proses konseling. ${ }^{15}$

Adapun tehnik-tehnik komunikasi interpersonal (terapeutik) yang dilakukan menurut Stuart dan Sunden (Mundakir, 2006:131), terdiri dari:

1. Mendengarkan dengan aktif (Active Listening) Seorang perawat semestinya mendengarkan secara aktif keluhan dari konseli. Dengan men-

\footnotetext{
${ }^{12}$ Gerald R. Miller (Editor). Exporation in Interpersonl Communication Vol. V. (Baverly Hills-London: Sage Publications, 1976), h. 15.

${ }^{13}$ Purwanto, Heri, Pengantar Perilaku Manusia Suatu Pengantar, (Jakarta, Penerbit Buku Kedokteran EGC, 2003).

${ }^{14}$ Kozier, B., et al. Fundamental of Nursing: Concepts, Process and Practice. (7th ed). (New Jersey: Prentice-Hall, Inc., 2004).

${ }^{15}$ Purwanto, Heri, Pengantar Perilaku Manusia Suatu Pengantar.
} 
degar, perawat mengetahui perasaan pasien, memberikan kesempatan yang banyak kepada pasien untuk berbicara dan mengungkapkan keluhannya. Misalnya, : "Silahkan ungkapkan semua perasaan dan keluhan saudara, saya akan mendengarkannya dengan baik".

2. Pertanyaan terbuka (Broad Opening) Memberikan kesempatan kepada pasien untuk mengungkapkan perasaanya.

3. Mengulang kembali (Restating)

4. Klarifikasi, dilakukan bila konselor ragu, tidak jelas, tidak mendengar atau konseli malu mengemukakan informasi atau keluhannya.

5. Refleksi isi dan perasaan. Refleksi merupakan reaksi konselor dan konseli selama berlangsungnya komunikasi.

6. Mengarahkan/memfokuskan pembicaraan.

7. Membagi persepsi konselor mengungkapkan persepsinya tentang konseli dan meminta umpan balik atau meminta respon dari tersebut.

8. Identifikasi tema/Mengeksploras.

9. Diam (Silence) Biasanya dilakukan setelah memberi pertanyaan. Tujuannya memberi kesempatan berfikir dan memotivasi konseli untuk berbicara.

10. Memberi informasi (Informing)

11. Memberi saran Memberi alternatif untuk pemecahan masalah.

Pelaksanaan Komunikasi Interpersonal konselor-konseli (Terapeutik) terdapat proses yang terbina melalui lima tahap dan setiap tahapnya mempunyai tugas yang harus dilaksanakan dan diselesaikan oleh konselor. Adapun tahapan komunikasi interpersonal (terapeutik), yaitu, prainteraksi, perkenalan, orientasi, tahap kerja, dan terminasi, yang dijabarkan sebagai berikut:

1. Prainteraksi. Prainteraksi merupakan masa persiapan sebelum berhubungan dan berkomunikasi dengan konselor. Konselor diharapkan tidak memiliki prasagka buruk kepada konseli, karena akan menggangu dalam membina hubungan dan saling percaya. Hal-hal yang dilakukan pada prainteraksi ini bisa meliputi analisis tingkah laku bermasalah yang dialami konseli saat ini; analisis situasi yang di dalamnya masalah konseli terjadi; analisis motivasional; analisis selfcontrol; analisis hubungan sosial; dan analisis lingkungan fisik-sosial budaya. 
2. Perkenalan. Perkenalan merupakan kegiatan yang pertama kali dilakukan oleh konselor terhadap konseli. Pada tahap ini, konselor dan konseli mulai mengembangkan hubungan komunikasi interpersonal yaitu, dengan memberikan salam, senyum, memberikan keramah-tamahan kepada pasien, memperkenalkan diri, menanyakan nama pasien dan menanyakan keluhan pasien, dan lain-lain.

3. Orientasi. Tahap orientasi merupakan tahap awal pertemuan sampai seterusnya selama konseli melaksanakan konseling. Tujuan tahap orientasi adalah memeriksa kondisi konseli, menvalidasi keakuratan data, rencana yang telah dibuat dengan keadaan konseli saat itu, dan mengevaluasi hasil tindakan. Pada tahap ini sangat diperlukan perasaan simpati dan empati agar konseli merasa tenang dan merasa dihargai.

4. Tahap kerja. Setelah merumuskan tujuan yang ingin dicapai, konselor dan konseli menentukan strategi belajar yang terbaik untuk membantu konseli mencapai perubahan tingkah laku yang diinginkan. Konselor dan konseli mengimplementasikan teknik-teknik konseling sesuai dengan masalah yang dialami oleh konseli.

Terminasi merupakan tahap akhir dalam komunikasi interpersonal dan akhir dari pertemuan antara konselor dan konseli. Proses konseling akan berakhir jika tujuan yang ditetapkan di awal konseling telah tercapai. Meskipun demikian, konseli tetap memiliki tugas, yaitu terus melaksanakan perilaku baru yang diperolehnya selama proses konseling, di dalam kehidupannya sehari-hari. ${ }^{16}$

\section{E. Kesimpulan}

Gejala kebosanan atau kejenuhan dalam menjalankan peran sebagai ibu rumah tangga meruapakan sebuah hal yang mungkin dianggap biasa, akan tetapi apabila gejala kebosanan yang berlarut akan berdampak pada stress. Alternatif langkah yang bisa dilakukan dalam rangka mengatasi gejala kebosanan pada ibu rumah tangga adalah dengan menggunakan komunikasi interpersonal dengan komunikasi terapeutik, adapun tahapannya yaitu: mendiagnosis problem-problem yang dialami oleh konseli ke 2003), h. 56.

${ }^{16}$ Christina Lia Uripni, dkk. Komunikasi Kebidanan, Jakarta: Penerbit Buku Kedokteran, 
dalam istilah tingkah laku, mengimplementasikan prinsip-rinsip tingkah laku dari penguat dan model, penggunaan model dan permainan peranan dalam proses penyembuhan.[]

\section{Daftar Pustaka}

Amparo Oliver, Jose Manuel Tomas and Alistair Cheyne, "Safety Climate : Its Nature and Predictive", Psychology in Spain, Vol. 10 No. 1, 2006.

Astuti, dkk, "Hubungan antara Kemandirian dengan Sikap terhadap Kekerasan Suami pada Istri yang Bekerja di Kelurahan Sampangan Kec. Gajah Mungkur Kota Semarang", Jumal Psikologi Universitas Diponegoro Vol.3 No. 1, Juni 2006.

Baron, R.A., dan Byrne, D., Psikologi Sosial, Jilid 2. Ed. X. Alih Bahasa: Ratna Djuwita. Jakarta: Erlangga, 2005.

Christina Lia Uripni, dkk., Komunikasi Kebidanan, Jakarta: Penerbit Buku Kedokteran, 2003.

Kozier, B., et al., Fundamental of Nursing: Concepts, Process and Practice. (7th ed). New Jersey: Prentice -Hall, Inc., 2004.

Liliweri, Alo, Komunikasi Antarpribadi, Bandung : Citra Aditya Bakti, 1991.

Miller, Gerald R. (ed.)., Exporation in Interpersonl Communication, Vol. V. Baverly Hills-London: Sage Publications, 1976.

Mundakir, Komunikasi Keperawatan : Aplikasi dalam Pelayanan, Yogyakarta: Graha Ilmu, 2006.

Nurjanah, Psikologi Perkembangan untuk Keperawatan, Jakarta: Penerbit Buku Kedokteran. EGC, 2001.

Purwanto, Heri, Pengantar Perilaku Manusia Suatu Pengantar, Jakarta, Penerbit Buku Kedokteran EGC, 2003.

al-Qarashi Baqir Sharif, Seni Mendidik Islami: Kiat-kiat Menciptakan Generasi Unggul, Jakarta: Pustaka Zahra, 2003.

Thackray, R., The Stress of Boredom and Monotony: A Consideration of the Evidence, Elsevier North Holland, Inc. New York, 1981. 
